\title{
Justification and Development of a Model of the Formation of Readiness Among Pedagogical University Students to Implement Aesthetic Education of Schoolchildren when Teaching Biology
}

\author{
Tatyana Ilinichna Kondaurova \\ Department of Theory and Methodology of Biological and \\ Chemical Education and Landscape Architecture \\ VOLGOGRAD STATE SOCIO-PEDAGOGICAL UNIVERSITY, \\ VSSPU \\ 400067, Volgograd, Russian Federation \\ kondtail@vspu.ru
}

\author{
Natalya Viktorovna Bocharnikova \\ Department of Foreign Languages
}

VOLGOGRAD STATE SOCIO-PEDAGOGICAL UNIVERSITY, VSSPU

400067, Volgograd, Russian Federation

bocharnikoff@mail.ru

\author{
Natalya Evgenievna Fetisova \\ Department of Theory and Methodology of Biological and Chemical Education and Landscape Architecture \\ VOLGOGRAD STATE SOCIO-PEDAGOGICAL UNIVERSITY, \\ VSSPU \\ 40067, Volgograd, Russian Federation \\ kinton79@mail.ru
}

\begin{abstract}
The theoretical justification, development, and testing of a model of the formation of readiness of pedagogical university students for implementation of aesthetic education of schoolchildren when teaching biology are presented. The analysis of scientific, pedagogical, and methodological literature has been carried out. The stages and contents of the model, the pedagogical conditions of its realization and the levels of students' readiness to implement aesthetic education of schoolchildren have been determined.
\end{abstract}

Keywords - aesthetic education of schoolchildren, students' readiness, model of formation of students' readiness, stages, contents of the model, pedagogical conditions, levels of formation of students' readiness, diagnostics.

\section{INTRODUCTION}

The need to improve aesthetic education of schoolchildren is due to a number of economic, psychological and pedagogical reasons:

- the depth and scale of occurring in Russia economic, social and spiritual processes require special attention to the process of forming harmoniously developed personality;

- Russia's overcoming the crisis is rightly associated with the spiritual and moral
- personality development (as A. Pechchei noted, if we want to change the world, first we have to change a person, his system of qualities and values);

- imperfection of social experience, lack of stability of youth beliefs necessitate the actualization of the process.

School biological education is aimed at fostering a comprehensively and harmoniously developed personality, ready for life and work in a modern society. An integral part of the education system is aesthetic education. It is necessary for the harmonious development of schoolchildren, because it stimulates their inherent ability to feel and perceive beauty in nature and art, reflecting the beauty of nature, as well as understand this beauty and develop the need to create and protect themselves, the beautiful in nature, work and around them - in everyday life, personal and social, to act beautifully [1].

Biological science has tremendous educational force, therefore, biology is actively used not only for the surrounding living world cognition, but also for teaching students correct understanding of the world, a scientific worldview, and for developing interest towards the surrounding world, people, their interests, actions, motives and life goals [2].

The perception of the beautiful in nature is closely connected with scientific knowledge, the development of interest towards nature and, ultimately, with love for the motherland. This has been noted by the most prominent 
methodologists - biologists (P.F. Kapterev, A.Ya. Gerd, A.N. Beketov, V.V. Polovtsev, B.E. Raikov, N.M. Verzilin, V.K. Korsunskaya, I.D. Zverev, I.N. Ponomareva, V.V. Nikolina and others).

Despite the breadth of knowledge in the scientific literature of the topic presented, the study of the experience of secondary school biology teachers in aesthetic education of schoolchildren made it possible to identify a number of contradictions between the importance and necessity of aesthetic education among students and the lack of detailed insight into theoretical and methodological foundations of the indicated problem. The controversy emerged is determined by a discrepancy between:

- modern society requirements fora teacher capable of effective realization of aesthetic education of schoolchildren, and the level of formation of teacher competencies, allowing to carry out this activity;

- the presence of scientific theory of the process of aesthetic education of schoolchildren and insufficient scientific and methodological support of the process of goal-oriented education of students through the subject "Biology";

- great potential of didactic means of the subject "Biology" and insufficient methodological elaboration of the problem for its implementation in school.

The essence of these contradictions and the need to resolve them have determined the relevance of the study: scientific research, specification of the content, pedagogical conditions, which can provide the training of a teacher for effective aesthetic education of secondary school students in the process of biological education.

\section{METHODOLOGICAL PART}

The methodological basis of the study has been formed by:

- the idea of educating a person in the context of culture (V.V. Ilyin, E.V. Bondarevskaya, M.S. Kagan, V.Ya. Nechaev, V.V. Serikov, N.M. Borytko, L.S. Vygotsky, M.L. Verb, N.A. Kumaev, B.T. Likhachev, S.T. Shatsky, L.G. Novikova, etc.);

- the research of scientists on theory, methods, practices of aesthetic education of schoolchildren (B.T. Likhachev, T.S. Komarova, N.P. Sakulina, G.P. Novikova, V.V. Nikolina, A.I. Burov, E.V. Kvyatkovsky, L.P. Pechko, P .P. Blonsky, N.I. Kiyashchenko, S.T. Shatsky, etc.);

- personality oriented education concept (teachers N.A. Alekseev, E.V. Bondarevskaya, V.A. Slastelin, V.V. Serikov, A.V. Tryapitsyna, A.V. Farmstead, I.S. Yakimanskaya; psychologists L.S. Vygotsky, A.N. Leontiev, D.B. Elkonin; methodologists N.M. Verzilin, I.D. Zverev, V.V. Nikolina, N.L. Stefanova, etc.);

- ideas and theories of the axiological approach in education (V.V. Kraevsky, I.Ya. Lerner, N.E. Schurkova, A.V. Kiryakova, M.M. Bakhtin, V.V. Serikov, L.S. Vygotsky, L.P. Razbegaev and others).
The importance of aesthetic education is explained by the fact that it has an exceptionally large impact on all other aspects of the human person formation, primarily, on his or her moral image. In different types of education, especially moral, it is very important that the rationalis reinforced and accompanied by emotional experience [3]. In the process of teaching biology aesthetic education should be multifaceted and conducted systematically in all forms of communication of students with nature and natural objects - in the classroom, during excursions, at the training experimental site, during extracurricular and out-of-class activities [4].

In methodological training, which is an important part of the professional development of bachelors and masters in biological education at the Volgograd State Socio-Pedagogical University, much attention is paid to preparing students for the implementation of aesthetic education among schoolchildren. Methodological training is considered as a system, including content, methods and pedagogical techniques, means and forms of organization of students teaching. The specific nature of the formation of students' methodological competence in the field of aesthetic education is inextricably linked with the development of a model of its content, which ensures the formation of methodological knowledge, skills, experience and personal professional qualities of prospective teachers [5].

The analysis of scientificand pedagogical, methodological literature allowed us to define the stages of designing the contents of the student training model for the aesthetic education of schoolchildren in biology teaching [6].

\section{STAGES OF MODEL IMPLEMENTATION}

The first step is to determine motivational targets. This stage involves the formation of students' motivation for the realization of aesthetic education when teaching biology, awareness of the importance of this type of activity, as well as readiness for its implementation [7].

Relying on approaches to the allocation of groups of motives in the works by O.S. Grebenyuk, N.K. Sergeev, the following groups of motives for implementation of aesthetic education of schoolchildren have been determined.

Broad social motives (in respect of society):

- awareness of the social significance of aesthetic education;

- moral duty motives of maintaining harmony of the world around.

Self-improvement motives (in respect of oneself):

- aspiration for harmony;

- desire for self-education;

- the desire to expand their horizons, acquire spiritual values, realize one's "I" in the world of nature and society, understand the meaning of one's of existence.

Motives for achievements (in respect of oneself): 
- the need for realization of aesthetic education;

- the need for self-expression and self-affirmation through the implementation of skills of harmonization of relations with the outside world, the awareness of its originality and uniqueness.

Motives for professional development (in respect of professional activity):

- the awareness of the need for aesthetic education of schoolchildren as one of the components of the biology teaching process.

\section{Motives of compulsion:}

- compulsory education of schoolchildren (including aesthetic) in accordance with the request of society, which is reflected in the regulatory documentation, the requirements of the school administration and parents.

The stated motives cover the main directions of the motivational sphere of personality [8].

As a matter of fact, during the first practical laboratory classes in the discipline "Methodology of teaching biology" students learn the components of the contents of biological education, regulatory documents, coming to the conclusion that this type of education is a necessary component of biological education, get to know the methods of forming this education of personality, develop questionnaires aimed at identifying its formation among schoolchildren [9].

The second stage includes the establishment of interdisciplinary connections with academic subjects ("Pedagogy", "Philosophy", "Culturology", "Psychology", etc.). The integrated study of the object of our research enables us both to learn as comprehensively as possible the individual components of the designed and tested model of the content of the methodological training of students in the sphere of aesthetic education of schoolchildren and to trace the dynamics

"Grandma's Garden", "Overgrown Pond", "Golden Autumn"; C. Monet "Apple Trees in Bloom", "Lilacs, Grey Weather". In addition, using multimedia tools, images of palaces and other buildings, in the interiors of which architects used floral ornaments, were demonstrated (The Raphael Loggias in the Hermitage, the damask in Catherine, Pavlovsk and Peterhov palaces, the parquet in Gatchina Palace and others). According to the students' opinion, these demonstrations develop cognitive interest, aesthetic taste, satisfy a person's spiritual needs for beauty. Thus, using the means of artistic images, we stressed the fact that nature serves not only as the basis for satisfying material wealth, but also it provides the source of inspiration, contemplation, study and creation of the beautiful [10].

If we take pedagogical experience, we can note an extensive use of artwork by biology teachers. Good pedagogical results are obtained by the use of artistic, scientifically reliable images created by V.A. Watagin, D. Adamson (images of animals and birds), V.S. Grebennikov (images of insects). of its development and transformation. According to N.D. Andreeva, N.O. Vereshchagina, I.N. Ponomareva, V.P. Solomin and other authors, this approach allows us to build the interpretation of the phenomena of pedagogical reality in terms of aesthetic education on the base of the combination (integration) of various approaches. The integration is based on the transfer of ideas and views from one field of knowledge to another, which allows us to use the conceptual apparatus, methods, didactic tools from different scientific areas more efficiently.

The third stage consists in determining the fundamental core of the content of the model of preparing students for aesthetic education of schoolchildren. This stage is connected with determination of biological concepts, providing aesthetic education of schoolchildren in accord with the units of school Biology course:

\section{- «Living organisms»; \\ - «Human and his body»; \\ - «General biological patterns».}

The analysis of the contents of the school biology course showed that in almost every topic one can use artistic images of different genres - painting, literature, architecture, music, decorative and applied art, photographs, folklore and so forth [1]. For example, students when developing methods of studying the topic "Diversity of the plant world", discussing the issue of biodiversity of plants, demonstrated reproductions of paintings with images of the plant world. Among them were the following paintings: I.I. Shishkin "In the Forest", "Birch Grove", "Beach of Pond", "Beech Forest in Switzerland"; A.K. Savrasov "Winter landscape", "Rye"; A.I. Kuindzhi "Birch Grove", "Steppe"; I.I. Levitan "March", "Autumn Leaves", "Forest Violets and forget-me-nots"; V.D. Polenov.

No less productive, in turn, is the use of factual material on the artistic work of biologists. Schoolchildren are interested in stories about the life and work of scientists combining scientific activities with art: J.-J. Russo, K.A. Timiryazev and others. In practice a large amount of material on the poetic work of learned biologists and folklore, collected by Academician E.N. Pavlovsky, has been methodically tested. Fragments from the works by N.A. Kholodkovsky, V.P. Filatova and other scholars help students realize that poetry can be a source of scientific knowledge that also stimulates art creation.

Working with artistic images, a teacher must pay attention to accuracy of scientific mapping of natural phenomena in works of literature and art. It is equally important to demonstrate the great importance of science as a source of beauty [11]. We should strive to develop among school students aesthetic pleasure from mental work, such as solving cognitive problems, cultivate a vision of beauty in logical reasoning of C. Darwin, K.A. Timiryazev and other scientists, in the accuracy and laconic formulations of the laws of 
genetics. When teaching biology, it is important both "The excitement of the mind by the beauty of nature," as V.O. Kovalevsky said, and an aesthetic assessment of scientific pursuits and discoveries. The story about the romance of the scientific inquiry of the great biologists shows beauty in the very process of cognition. The books by V.M. Korsunsky about great naturalists can serve as an example.

An important condition for the aesthetic education of school students is the need to develop their sense of pleasure from the beauty created by their own hands (whether it be a herbarium or planting trees), the formation of the need to appreciate the beautiful and overcome the ugly and unaesthetic in the environment [12]

Socially significant results of schoolchildren's activities (educational visual aids, creation of green spaces, etc.) also present aesthetic value. The main source of aesthetic education is the school students' activity organized by a teacher. In a variety of school students' creative activities, a teacher should note individual preferences of the students, support their desire for aesthetic self-expression.

The fourth stage involves the inclusion of students in methodological activities and the formation of their methodological competence in the field of aesthetic education of schoolchildren. The inclusion of students in methodological activities was carried out in a variety of forms and types of activity. Students received initial skills in laboratory and practical classes and during their independent study:

- when doing practical tasks in laboratory and practical classes in discipline "Methodology of teaching biology", aimed at improving the methodology of aesthetic education of schoolchildren during biology classes, implemented in the form of a business game;

- in the course of students' independent work, devoted to the arrangement of outing, thematic excursions to exhibitions, extracurricular activities of an aesthetic character;

- when writing term papers and graduation projects.

Practice of the acquired skills related to the aesthetic education of schoolchildren, took place during the teaching practice at school, in times of organization and conducting thematic competitions for students in grades 6-11, etc.

The fifth stage is reflection, which is determined by the effectiveness of the methodological preparation of students. The assessment of the level of formation of competence among students to complement aesthetic education of schoolchildren in biology classes was carried out using diagnosis at different stages of methodological training.

\section{DIAGNOSTICS}

The initial diagnosis was used to identify the level of knowledge and skills of biology students for implementing the aesthetic education of schoolchildren. It let the students build the individual path of correction route. The current diagnosis was carried out to timely assess the effectiveness of pedagogical procedures, aimed at preparing students for aesthetic education of schoolchildren [13].

The levels of students' readiness for implementation of aesthetic education of schoolchildren have been determined: elementary (reproductive), adaptive (intermediate), creative (advanced). At the elementary level, students' knowledge of the school subject "Biology" in respect of aesthetic education of schoolchildren is not enough, it is fragmentary. This level is characterized by low quality knowledge of the content of biological material and methods, allowing to effectively carryout aesthetic education. Reproductive activity and dependence on ready-made guidelines predominate. At an intermediate level, students have a sufficient amount of knowledge and skills in aesthetic education of schoolchildren, they are able to apply them in the process of teaching biology at school. The peculiar feature is a gradual adaptation to the mechanism of the implementation of aesthetic education of schoolchildren, which is associated with the development of motivation due to the involvement of students in solving problems and situations that mimic the professional activity of a biology teacher [2]. At an advanced level, students have an extensive body of knowledge about methodology of aesthetic education of schoolchildren in biology education, they are able to select material containing aesthetic aspect, in each section of biology, establish interdisciplinary connections, have the necessary methods and pedagogical techniques, have experience in organizing aesthetic education of schoolchildren [14].

The final diagnosis included the application of the analysis of the results of educational activities, a survey, observation in order to determine the level of acquired knowledge, skills for the implementation of aesthetic education of schoolchildren [8]. In general, the primary, current and final diagnosis performs the function of control and determines the mechanisms of regulation, correction and improvement of the process of preparing students for the implementation of aesthetic education of schoolchildren in biology classes [15].

\section{RESULTS}

The results of the experimental work have shown that when constructing the process of preparing students for the implementation of aesthetic education of schoolchildren in biology classes positively important advancements of all components of the investigated education of an individual are achieved. During the experiment significant data have been obtained. The students have achieved advanced $(12,6 \%$ of the students from the experimental group, at the beginning of the experimental work $-8,1 \%)$ and intermediate $(54,1-48,7 \%)$ levels of formation of readiness for the implementation of aesthetic education of schoolchildren. It is the evidence of the progress of an individual's studied education, taking place during the experiment.

\section{REFERENCES}

[1] Kraevsky V.V., «What to learn?», Academic journal published «Educational Studies Moscow», vol.3, pp. 5-23, 2004. 
[2] Danilov D.A., Kornilova A.G., «Problems of renewal of regional education», Scientific and theoretical journal Russian Academy of Education «Pedagogika», vol.7, pp.51-55, 2017.

[3] A.A. Azbel, V. S. Bratash, T. G. Galaktionova, M. I. Grineva, G. V. Danilova, L. S. Ilyushin, E. I. Kazakova, V. E. Pugach, G. N. Chen, «Classical literature in the thoughts and feelings of modern adolescents: an attempt at pedagogical research» Scientific and theoretical journal Russian Academy of Education «Pedagogika»,vol., pp. 39-54, 2019.

[4] Shcherbakov R.N., «Aesthetic principle in teaching the Sciences basics», Scientific and theoretical journal Russian Academy of Education «Pedagogika», vol.7, pp. 46-51, 2010.

[5] Gazman O.S., «Does a democratic school need any education program?», Academic journal published «Educational Studies Moscow», vol.2, pp. 7-14, 2013.

[6] Perminova L.M., «The significance of V.Kraevsky's works for the development of Pedagogics and Didactics», Scientific and theoretical journal Russian Academy of Education «Pedagogika», vol.3, pp.1320, 2019.

[7] Malyarchuk N.N., Madzhuga A.G., Agzamov R.R., «Education as a socio-cultural context of the individual"s health-building position», Scientific and theoretical journal Russian Academy of Education «Pedagogika», vol.10, pp.56-61, 2017.

[8] Dykhanova B.S., «Educational technology as "task" system of training ways», Scientific and theoretical journal Russian Academy of Education «Pedagogika», vol.5, pp. 42-50, 2015.
[9] B.M. Nemenskiy, «The problems of the arts' educational significance: art as a tool for cognition and organization of life», Scientific and theoretical journal Russian Academy of Education «Pedagogika», vol.7, pp. 23-33, 2018.

[10] Shustova I.Ju., «Education in co existence: situational pedagogy», Scient ific and theoretical journal Russian Academy of Education «Pedagogika», vol.1, pp. 53-60, 2018.

[11] Nikolay D. Podufalov, «On some methodological problems of the education system development», Scientific and theoretical journal Russian Academy of Education «Pedagogika», vol.3, pp. 5-11, 2019.

[12] Zharkovskaya T.G., N.S. Kupriyanova, «Integration of educational potential natural-science and social arts education», Scientific and theoretical journal Russian Academy of Education «Pedagogika», vol.5, pp. 43-47, 2016.

[13] Dikareva I.G., «Informacionnaja dejatel'nost' kak komponent soderzhanija processa metodicheskoj podgotovki studentov-biologov pedagogicheskom vuze». Candidate of Pedagogic Sciences dissertation, Herzen University, St. Petersburg, Russia, 2014.

[14] Zharkovskaya T.G., Sinelnikov I.Yu., «An integrative approach as a means of interaction between disciplines», Scientific and theoretical journal Russian Academy of Education «Pedagogika», vol.8, pp. 9195, 2018

[15] Gasanova Zh.T., «Jesteticheskoe vospitanie shkol'nikov sredstvami fol'klora». Candidate of Pedagogic Sciences dissertation, DGPU, Mahachkala, 2013. 